\title{
Quantitative phosphoproteome analysis of embryonic stem cell differentiation toward blood
}

\author{
Manuela Piazzi ${ }^{1}$, Andrew Williamson ${ }^{2}$, Chia-Fang Lee $^{2}$, Stella Pearson ${ }^{3}$, Georges

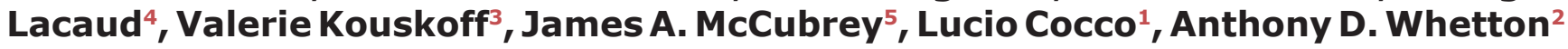 \\ ${ }^{1}$ Cell Signaling Laboratory, Department of Biomedical Science (DIBINEM), University of Bologna, Italy \\ ${ }^{2}$ Stem Cell and Leukaemia Proteomics Laboratory, Manchester Academic Health Science Centre, The University of Manchester, \\ Manchester, UK \\ ${ }^{3}$ Stem Cell Research Group, Manchester Academic Health Science Centre, University of Manchester, Manchester, UK \\ ${ }^{4}$ Stem Cell Biology Group Paterson Institute for Cancer Research, Manchester Academic Health Science Centre, University \\ of Manchester, Manchester, UK \\ ${ }^{5}$ Department of Microbiology and Immunology, Brody School of Medicine at East Carolina University, Greenville, NC, USA \\ Correspondence to: \\ Manuela Piazzi, e-mail: manuela.piazzi3@unibo.it
}

Keywords: hemangioblast, iTRAQ, phosphoproteomic, nucleus

Received: January 27, $2015 \quad$ Accepted: February 24, $2015 \quad$ Published: March 26, 2015

\section{ABSTRACT}

Murine embryonic stem (ES) cells can differentiate in vitro into three germ layers (endodermic, mesodermic, ectodermic). Studies on the differentiation of these cells to specific early differentiation stages has been aided by an ES cell line carrying the Green Fluorescent Protein (GFP) targeted to the Brachyury (Bry) locus which marks mesoderm commitment. Furthermore, expression of the Vascular Endothelial Growth Factor receptor 2 (FIk1) along with Bry defines hemangioblast commitment. Isobaric-tag for relative and absolute quantification (iTRAQ ${ }^{\mathrm{TM}}$ ) and phosphopeptide enrichment coupled to liquid chromatography separation and mass spectrometry allow the study of phosphorylation changes occurring at different stages of ES cell development using Bry and Flk1 expression respectively. We identified and relatively quantified 37 phosphoentities which are modulated during mesoderm-induced ES cells differentiation, comparing epiblast-like, early mesoderm and hemangioblastenriched cells. Among the proteins differentially phosphorylated toward mesoderm differentiation were: the epigenetic regulator Dnmt3b, the protein kinase GSK3b, the chromatin remodeling factor Smarcc1, the transcription factor Utf1; as well as protein specifically related to stem cell differentiation, as Eomes, Hmga2, Ints1 and Rif1. As most key factors regulating early hematopoietic development have also been implicated in various types of leukemia, understanding the post-translational modifications driving their regulation during normal development could result in a better comprehension of their roles during abnormal hematopoiesis in leukemia.

\section{INTRODUCTION}

Mouse embryonic stem cells (mESCs) are the in vitro counterparts of an in vivo population of cells specific to the early embryo within the inner cell mass. ES cells are pluripotent and different culture conditions can induce them to differentiate into the three primary germ layers (mesoderm, ectoderm and endoderm). In the mouse embryo around 6.5 days of gestation, epiblast cells migrate to form the primitive streak which contains the nascent mesoderm. Derived from mesoderm, hematopoiesis occurs in a consequent temporal pattern during embryonic development, around 7.5 days gestation in the blood islands in the yolk sac. Associated with this process is the formation of the hemangioblast population. This transient progenitor cell with the capacity to give rise to both endothelial and hematopoietic progenitors has been shown to be formed within the primitive streak [1].

mESCs have been studied extensively since they represent a potentially vast source of cells and tissues 
for regenerative medicine. Although there are data on the molecular processes governing the formation of hemangioblasts [2], specific phosphorylation events within the nucleus governing development have not yet been systematically analysed, and the mechanistic detail on how the hemangioblast is formed requires further analysis.

To further delineate the hemangioblast population, a reporter ES cell line with the GFP coding sequences targeted into the Brachyury (Bry) locus was created by Fehling et al [3]. ES cells can differentiate in vitro to form spheroid cultures called embryonic bodies (EBs). These structures contain the derivatives of all the three germ layers, and it is possible to track mesoderm and hematopoietic lineage commitment in vitro with the temporal expression of two specific genes, restricted to the lineage of interest. Bry, a member of the T-box gene family, is a marker for the early mesoderm formation (the majority of the cells in the primitive streak are Bry positive). Bry expression decreases when cells migrate away from the primitive streak and further differentiate. Flk1, the vascular endothelial growth factor receptor 2, identifies a mesodermal population of cells further committed for differentiation and is commonly expressed with Bry in populations with hematopoietic potential. The analysis of Bry and Flk1 expression allowed for the detection of three subpopulations: the Bry-Flk1- population represents mES cells that have not yet undergone the differentiation process, thus resembling epiblast cells. The $\mathrm{Bry}^{+} \mathrm{Flk}^{-}$fraction corresponds to a population of early mesoderm differentiating cells. The $\mathrm{Bry}^{+} \mathrm{Flk}^{+}$fraction contains precursors for endothelial and hematopoietic lineages, the blast-colony forming cells (BL-CFC), representing the in vitro equivalent of the hemangioblast.

We have previously reported changes occurring in mES cells nuclear proteome during mesoderm-induced differentiation, using isobaric tags for relative and absolute quantification (iTRAQ ${ }^{\mathrm{TM}}$ ) coupled to LC-MS/MS analysis [4]. This approach allowed a relatively deep proteomic penetration. However, activities of proteins are often regulated by translation and degradation rates, as well as by post-translational modifications, e.g. phosphorylation. It has been recently reported that post-translational modifications occur during ES cells differentiation, and they are also required for ES cell self-renewal [5]. Protein phosphorylation has been demonstrated to be involved in the regulation of many aspects of cellular functions including cell proliferation, differentiation, migration and signal transduction. It is likely that extracellular signals in part convey their signals to the nucleus to engender epigenetic changes to initiate altered gene transcription [6]. In the process of mesoderm formation some signaling molecules have defined roles in proliferation and development control, such as tumor growth factor beta, FGF, Wnt and Hedgehog families; in mouse, BMP4, Wnt3 or Nodal, are essential for mesoderm development [7-8]. Mice lacking canonical Wnt ligands do not develop the primitive streak and fail to generate mesoderm from the epiblast [9-11]. Therefore the Wnt signaling pathway is involved in the mechanism that induces mouse ES cells to differentiate, switching from self-renewal to differentiation. Phosphorylation mapping, by means of proteomic technologies, serves as a starting point for establishing a comprehensive database of the stem cell phosphoproteome. To define the phosphoproteome of hemangioblast cells, we compared it with that of epiblast-like and early mesoderm populations. Our observations provide potential new pathways for analysis of regulation in ES cell differentiation to the hemangioblast fate, that could also be unraveled in leukemias. Interestingly, recent findings propose a pivotal role for GSK3 and the chromatin remodeling factor Smarcc1/Baf155 in the decision fate of hematopoietic stem cells to differentiate. GSK3 is an important regulator of stem cell homeostasis, in particular ES cell self-renewal [12], but it also been recently implicated in leukemia stem cell physiology [13-14]. Smarcc1/Baf155 is necessary for heterochromatin formation and chromatin compaction during the differentiation process.

\section{RESULTS}

\section{Phosphoproteomic analysis of early embryonic development}

Once cultured without LIF and embryonic feeders, ES cells differentiate in vitro toward the mesoderm lineage. Three different populations, Bry-Flk1 ${ }^{-}, \mathrm{Bry}^{+} \mathrm{F} 1 \mathrm{k} 1^{-}$ and $\mathrm{Bry}^{+} \mathrm{Flk}^{+}$, were isolated from the differentiating ES cell culture as previously described [3] (Figure 1A). These distinct populations have been seen to represent epiblast, mesoderm committed and blast like colony forming (BL-CFC) cells. Approximately $1 \times 10^{7}$ cells were collected for each population, nuclear enrichment was performed to concentrate the downstream proteomic analysis on pathways associated with regulation of gene expression (Figure S1). The same amount of each nuclear protein tryptic lysates $(100 \mu \mathrm{g})$ was labeled with one of the 4-plex iTRAQ ${ }^{\mathrm{TM}}$ channel reagents. All four reagents were used, allowing one internal control within the same LC-MS/MS experiment (Bry-Flk1- nuclear lysate was labeled with two different $\mathrm{iTRAQ}^{\mathrm{TM}}$ reagents) (Figure 1B). The samples were combined and enrichment for phosphopeptides performed using the $\mathrm{TiO}_{2}$ metal affinity enrichment approach. Samples were fractionated using SCX chromatography, before LC-MS/MS analysis. Data recorded from two independent biological replicates were analyzed using the Paragon Algorithm within the ProteinPilot ${ }^{\mathrm{TM}}$ v.3.0. The total number of phosphopeptides identified was 2506 , present in the two biological replicates, with $20 \%$ of confidence (Table S1). The data acquired showed a normal distribution between biological replicates with a modal value centered around 0 (1 in the linear scale) (Figure 1C). 
A

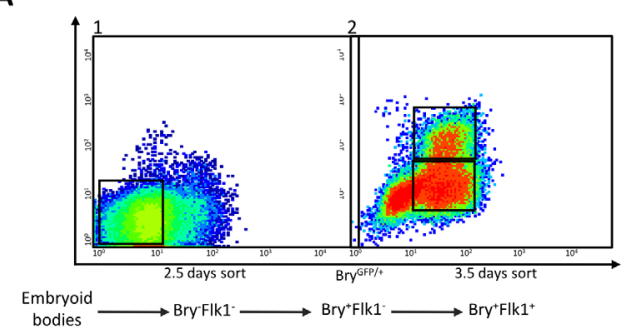

C

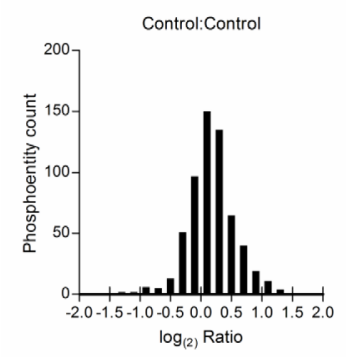

B

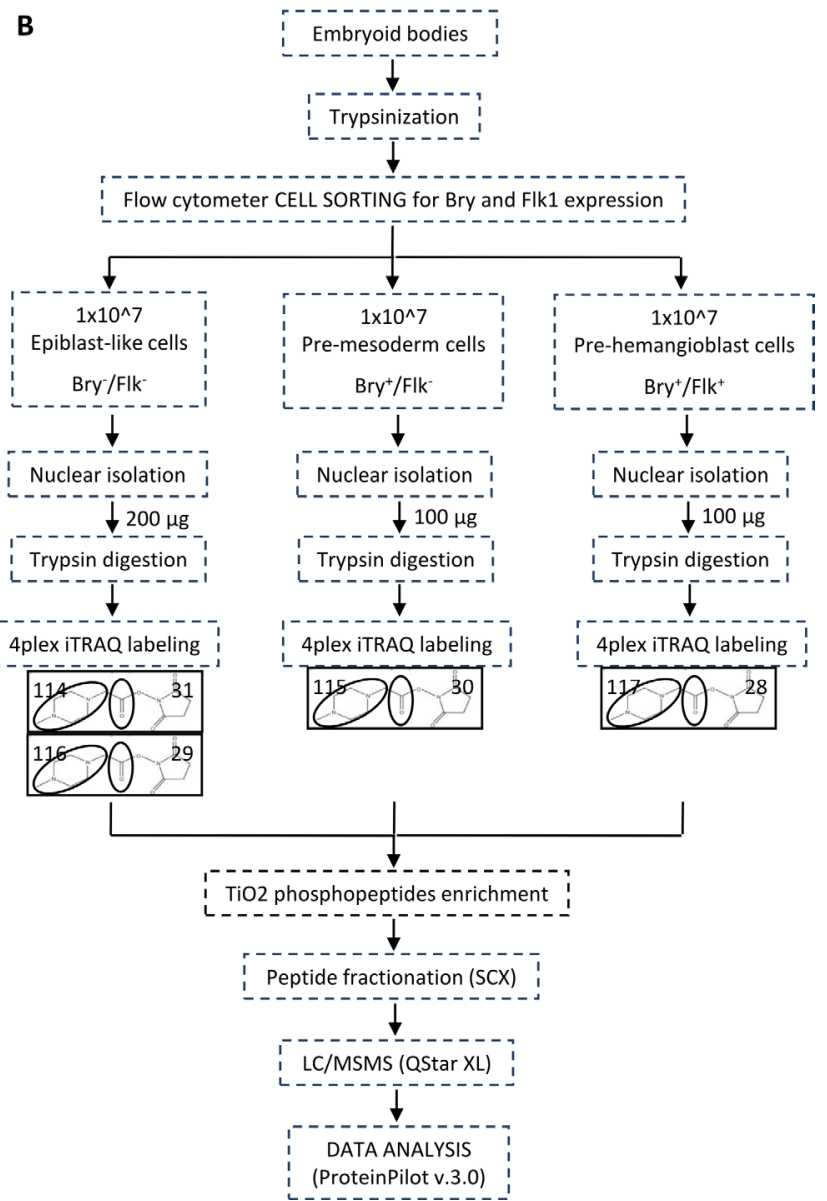

Figure 1: . (A) Flow cytometric sorting of ES cells at specific time points of the hematopoietic differentiation for nuclear phosphoproteome analysis. Differentiating ES cells were enriched based on Bry and Flk1 expression. $2 \times 10^{7}$ cells were used for each experiment. At 2.5 days of differentiation, Bry-Flk1 cells, corresponding to the epiblast-like stage, were collected by flow cytometric sorting (1). At 3.5 days two other populations, Bry ${ }^{+} \mathrm{Flk1} 1^{-}$and $\mathrm{Bry}^{+} \mathrm{Flk} 1^{+}$, corresponding to the mesoderm and hemangioblast (BL-CFC) cell populations, respectively, were collected (2). (B) Schematic workflow for the identification of changes in the phosphoproteome of mouse embryonic stem cells committed to the hematopoietic differentiation. Mouse embryonic stem cells sorted for Bry and Flk1 were generated from biological replicates. $100 \mu \mathrm{g}$ of nuclear lysate were digested with trypsin to produce peptides that were labeled with 4-plex iTRAQ ${ }^{\mathrm{TM}}$ reagent. Combined samples were then enriched for phosphopeptides via $\mathrm{TiO}_{2}$ column, separated with strong cation exchange chromatography (SCX) and subjected to nano-RPLC-MS/MS on a QTof mass spectrometer. (C) Distribution of the phosphoentity quantification ratios. Data normalization was obtained transforming all control ratios of phosphoentities identified with a sequence confidence above $20 \%$ with the logarithmic function at the base 2 (bins ranging from -2 to 2 ).

\section{Relative quantification of phosphorylation changes occurring in the hemangioblast formation}

Significance thresholds and quantitative phosphorylation changes were determined according to previous analysis [4-15-16]. To establish whether there was a change in peptide phosphorylation, only phosphopeptides exceeding $95 \%$ of the identifications compared to the control:control ratio (Bry ${ }^{-} \mathrm{Flk}^{-}$: Bry $^{-} \mathrm{Flk}^{-}$) were considered. The interval of significance was calculated for each replicate based on the normal distribution of the internal control ratio (Figure 1C). Phosphorylation level was considered significantly changing when the fold change was $<0.6$ (decrease) or $>1.5$ (increase). Phosphopeptides with a ratio within the intervals of significance were manually removed from the data. Spectra were then manually checked to verify phosphorylation assignment, based on intact fragment presence, neutral loss of $\mathrm{HPO}_{3}(80 \mathrm{Da})$ or neutral loss of $\mathrm{H}_{3} \mathrm{PO}_{4}(98 \mathrm{Da})$. Using these stringent selection criteria 37 phosphoentities were of interest as they change during ES cell differentiation (see Table 1). With the exception of Vars, the phosphopeptides have been also identified in other phosphoproteomic analyses [17-20]. For only 9 phosphopeptides, the modification site and the protein kinase were determined using site-specific methods (referring to the phosphorylation site repository found on http:/www. phosphosite.org/: 178226 non-curated sites, 103952 sites curated from literature) (Table 2). Regarding those peptides included in Table 1, epiblast cells shown 7 phosphoentities up-regulated and 14 phosphoentities down-regulated; early mesoderm cells exhibited 6 phosphoentities up-regulated and 
Table 1: Phosphopeptides identified as changing in differentiating ES on analysis of iTRAQ ${ }^{\mathrm{TM}}$ relative quantification.

\begin{tabular}{|c|c|c|c|c|c|c|c|c|}
\hline Acc.nb & $\begin{array}{l}\text { Gene } \\
\text { name }\end{array}$ & $\begin{array}{l}\text { Protein } \\
\text { name }\end{array}$ & $\begin{array}{c}\text { Phosphopeptide } \\
\text { sequence }\end{array}$ & $\begin{array}{l}\text { Bry }^{+} \text {Flk-: } \\
\text { Bry-Flk- }\end{array}$ & $\begin{array}{l}\text { Bry }^{+} \text {Flk }^{+}: \\
\text {Bry }^{+} \text {Flk }\end{array}$ & $\begin{array}{l}\text { Bry }^{+} \text {Flk }^{+}: \\
\text {Bry'Flk }\end{array}$ & $\begin{array}{c}\text { GO Biological } \\
\text { Process }\end{array}$ & $\begin{array}{c}\text { GO } \\
\text { Molecular } \\
\text { Function }\end{array}$ \\
\hline P57776 & Eefld & $\begin{array}{l}\text { eEF1d } \\
\text { protein }\end{array}$ & $\begin{array}{l}\text { GATPAEDDE } \\
\text { DKDIDLFG } \\
\text { pSDEEEEDKEAAR }\end{array}$ & 1.5 & 1.09 & 1.61 & $\begin{array}{l}\text { Positive } \\
\text { regulation of } \\
\text { NF-kB cascade }\end{array}$ & \begin{tabular}{|l|} 
Signal \\
transducer \\
activity; \\
Translational \\
elongation \\
factor activity
\end{tabular} \\
\hline P57776 & Eefld & $\begin{array}{l}\text { eEF1d } \\
\text { protein }\end{array}$ & $\begin{array}{l}\text { ATAPQTQ } \\
\text { HVpSPMR }\end{array}$ & 1.96 & 0.77 & 1.48 & $\begin{array}{l}\text { Positive } \\
\text { regulation of } \\
\text { NF-kB cascade }\end{array}$ & $\begin{array}{l}\text { Signal } \\
\text { transducer } \\
\text { activity; } \\
\text { Translational } \\
\text { elongation } \\
\text { factor activity }\end{array}$ \\
\hline Q6J1H4 & Utf1 & UTF1 & $\begin{array}{l}\text { RLPAFSPP } \\
\text { SPApSPDAELR }\end{array}$ & 0.36 & 0.5 & 0.17 & $\begin{array}{l}\text { Transcription, } \\
\text { DNA-dependent }\end{array}$ & $\begin{array}{l}\text { Transcription } \\
\text { coactivator } \\
\text { activity }\end{array}$ \\
\hline Q6J1H4 & Utf1 & UTF1 & $\begin{array}{l}\text { RLPAFpSPPS } \\
\text { PApSPDAELR }\end{array}$ & 0.38 & 0.42 & 0.16 & $\begin{array}{l}\text { Transcription, } \\
\text { DNA-dependent }\end{array}$ & $\begin{array}{l}\text { Transcription } \\
\text { coactivator } \\
\text { activity }\end{array}$ \\
\hline Q6J1H4 & Utf1 & UTF1 & $\begin{array}{l}\text { RLPAFSPP } \\
\text { pSPASPDAELR }\end{array}$ & 0.37 & 0.54 & 0.2 & $\begin{array}{l}\text { Transcription, } \\
\text { DNA-dependent }\end{array}$ & $\begin{array}{l}\text { Transcription } \\
\text { coactivator } \\
\text { activity }\end{array}$ \\
\hline Q6J1H4 & Utf1 & UTF1 & $\begin{array}{l}\text { RLPAFSPP } \\
\text { pSPApSPDAELR }\end{array}$ & 0.31 & 0.58 & 0.18 & $\begin{array}{l}\text { Transcription, } \\
\text { DNA-dependent }\end{array}$ & $\begin{array}{l}\text { Transcription } \\
\text { coactivator } \\
\text { activity }\end{array}$ \\
\hline Q6J1H4 & Utf1 & UTF1 & $\begin{array}{l}\text { SAGDVPVTTS } \\
\text { DAFATSGGM } \\
\text { AEPGpSPK }\end{array}$ & 0.39 & 0.48 & 0.19 & $\begin{array}{l}\text { Transcription, } \\
\text { DNA-dependent }\end{array}$ & $\begin{array}{l}\text { Transcription } \\
\text { coactivator } \\
\text { activity }\end{array}$ \\
\hline P17095 & Hmgal & $\begin{array}{l}\text { High mobility } \\
\text { group protein } \\
\text { HMG-I/HMG-Y }\end{array}$ & $\begin{array}{l}\text { KQPPV } \\
\text { pSPGTALVGSQK }\end{array}$ & 1.22 & 0.59 & 0.73 & $\begin{array}{l}\text { Regulation of } \\
\text { transcription; } \\
\text { DNA-dependent, } \\
\text { Negative } \\
\text { regulation of cell } \\
\text { proliferation }\end{array}$ & $\begin{array}{l}\text { DNA- } \\
\text { binding; } \\
\text { Transcription } \\
\text { coactivator } \\
\text { activity }\end{array}$ \\
\hline P52927 & Hmga2 & $\begin{array}{l}\text { High mobility } \\
\text { group protein } \\
\text { HMG-A2 }\end{array}$ & $\begin{array}{l}\text { KQQQEPTCEP } \\
\text { pSPKRPR }\end{array}$ & 1.29 & 1.89 & 2.38 & $\begin{array}{l}\text { Positive } \\
\text { regulation } \\
\text { of stem cell } \\
\text { proliferation }\end{array}$ & $\begin{array}{l}\text { A-T DNA } \\
\text { binding }\end{array}$ \\
\hline Q9CQS8 & Sec61b & Sec61 beta subunit & $\begin{array}{l}\text { PGPTPSGTNVGS } \\
\text { pSGRSPSK }\end{array}$ & 1.07 & 1.61 & 1.71 & Protein transport & $\begin{array}{l}\text { Ribosome } \\
\text { binding }\end{array}$ \\
\hline Q9CQS8 & Sec61b & Sec61 beta subunit & $\begin{array}{l}\text { PGPTPSGTNV } \\
\text { GSSGRpSPSK }\end{array}$ & 1.1 & 1.52 & 1.63 & Protein transport & $\begin{array}{l}\text { Ribosome } \\
\text { binding }\end{array}$ \\
\hline P30999 & Ctnnd1 & $\begin{array}{l}\text { Catenin delta- } 1 \\
\text { (p120 catenin) }\end{array}$ & GSLApSLDSLRK & 0.78 & 0.62 & 0.48 & $\begin{array}{l}\text { Wnt receptor } \\
\text { signaling } \\
\text { pathway; } \\
\text { Regulation of } \\
\text { transcription, } \\
\text { DNA-dependent }\end{array}$ & $\begin{array}{l}\text { Protein } \\
\text { phosphatase } \\
\text { binding; } \\
\text { Protein kinase } \\
\text { binding }\end{array}$ \\
\hline
\end{tabular}

(Continued) 


\begin{tabular}{|c|c|c|c|c|c|c|c|c|}
\hline Acc.nb & $\begin{array}{l}\text { Gene } \\
\text { name }\end{array}$ & $\begin{array}{l}\text { Protein } \\
\text { name }\end{array}$ & $\begin{array}{l}\text { Phosphopeptide } \\
\text { sequence }\end{array}$ & $\begin{array}{l}\text { Bry }^{+} \text {Flk-: } \\
\text { Bry-Flk- }\end{array}$ & $\begin{array}{l}\text { Bry }^{+} \text {Flk }^{+}: \\
\text {Bry }^{+} \text {Flk }\end{array}$ & $\begin{array}{l}\text { Bry }^{+} \text {Flk }^{+}: \\
\text {BryFlk }\end{array}$ & $\begin{array}{c}\text { GO Biological } \\
\text { Process }\end{array}$ & $\begin{array}{c}\text { GO } \\
\text { Molecular } \\
\text { Function }\end{array}$ \\
\hline Q8K019 & Bclaf1 & $\begin{array}{l}\text { Bcl-2-associated } \\
\text { transcription factor }\end{array}$ & IDIpSPSALRK & 0.53 & 1.35 & 0.7 & $\begin{array}{l}\text { Regulation of } \\
\text { transcription, } \\
\text { DNA-dependent; } \\
\text { Positive } \\
\text { regulation of } \\
\text { apoptosis }\end{array}$ & $\begin{array}{l}\text { Protein } \\
\text { binding; DNA } \\
\text { binding }\end{array}$ \\
\hline Q9WV60 & Gsk3b & $\begin{array}{l}\text { Glycogen } \\
\text { synthase } \\
\text { kinase } 3 b\end{array}$ & GEPNVpSYICSR & 0.15 & 1.48 & 1.67 & $\begin{array}{l}\text { Genetic } \\
\text { imprinting; } \\
\text { Multicellular } \\
\text { organismal } \\
\text { development; } \\
\text { Wnt receptor } \\
\text { signaling } \\
\text { pathway }\end{array}$ & $\begin{array}{l}\text { Protein kinase } \\
\text { binding; } \\
\text { Transferase } \\
\text { activity }\end{array}$ \\
\hline O88509 & Dnmt3b & $\begin{array}{l}\text { DNA } \\
\text { (cytosine-5) } \\
\text { methyltrans- } \\
\text { ferase 3B }\end{array}$ & $\begin{array}{l}\text { TTNDSAASE } \\
\text { pSPPPKR }\end{array}$ & 0.38 & 0.51 & 0.19 & $\begin{array}{l}\text { Methylation: } \\
\text { Epigenetic }\end{array}$ & $\begin{array}{l}\text { Transferase } \\
\text { activity }\end{array}$ \\
\hline Q01320 & Top2a & $\begin{array}{l}\text { Topoisomerase } \\
\text { (DNA) II alpha }\end{array}$ & $\begin{array}{l}\text { KPIKYLEE } \\
\text { pSDDDDDLF }\end{array}$ & 0.52 & 1.58 & 0.81 & $\begin{array}{l}\text { ATP catabolic } \\
\text { process; Mitotic } \\
\text { recombination; } \\
\text { Embryonic } \\
\text { cleavage }\end{array}$ & $\begin{array}{l}\text { DNA } \\
\text { topoisomerase } \\
\text { activity; } \\
\text { Chromatin } \\
\text { binding }\end{array}$ \\
\hline P14733 & Lmnb1 & Lamin B1 & LKLpSPSPSSR & 0.64 & 0.77 & 0.48 & $\begin{array}{l}\text { G2/M-specific } \\
\text { positive } \\
\text { regulation of } \\
\text { cyclin-dependent } \\
\text { protein kinase } \\
\text { activity Positive } \\
\text { regulation of } \\
\text { JNK cascade }\end{array}$ & $\begin{array}{l}\text { JUN kinase } \\
\text { binding; } \\
\text { Phospholipase } \\
\text { binding }\end{array}$ \\
\hline Q8BTI8 & Srrm2 & $\begin{array}{l}\text { Serine/arginine } \\
\text { repetitive matrix } 2\end{array}$ & $\begin{array}{l}\text { MVQASSQSLLP } \\
\text { PAQDRPRp } \\
\text { SPVPSAFSDQSR }\end{array}$ & 0.59 & 0.78 & 0.46 & $\begin{array}{l}\text { RNA splicing; } \\
\text { mRNA } \\
\text { processing }\end{array}$ & $\begin{array}{l}\text { Protein } \\
\mathrm{N} \text {-terminus } \\
\text { binding }\end{array}$ \\
\hline Q569Z6 & Thrap3 & $\begin{array}{l}\text { Thyroid hormone } \\
\text { receptor } \\
\text { associated protein } \\
3\end{array}$ & RIDIpSPSTFR & 0.56 & 1 & 0.55 & $\begin{array}{l}\text { Steroid hormone } \\
\text { receptor } \\
\text { signaling } \\
\text { pathway; } \\
\text { Transcription - } \\
\text { DNA dependent }\end{array}$ & $\begin{array}{l}\text { Transcription } \\
\text { coactivator } \\
\text { activity; } \\
\text { Nucleotide } \\
\text { binding }\end{array}$ \\
\hline P97496 & Smarcc 1 & $\begin{array}{l}\text { SWI/SNF } \\
\text { complex } 155 \mathrm{kDa} \\
\text { subunit }\end{array}$ & $\begin{array}{l}\text { RKPpSP } \\
\text { pSPPPPTATESR }\end{array}$ & 1.6 & 0.75 & 1.2 & $\begin{array}{l}\text { Chromatin } \\
\text { remodeling; } \\
\text { Organ } \\
\text { morphogenesis; } \\
\text { Transcription, } \\
\text { DNA-dependent }\end{array}$ & $\begin{array}{l}\text { Protein } \\
\text { binding; } \\
\text { DNA binding }\end{array}$ \\
\hline Q8VDF2 & Uhrf1 & $\begin{array}{l}\text { E3 ubiquitin- } \\
\text { protein ligase } \\
\text { UHRF1 }\end{array}$ & $\begin{array}{l}\text { RPLIA } \\
\text { pSPSQPPPALR }\end{array}$ & 0.82 & 0.7 & 0.56 & $\begin{array}{l}\text { Cell } \\
\text { proliferation; } \\
\text { Regulation of } \\
\text { transcription, } \\
\text { DNA- } \\
\text { dependent; } \\
\text { Multicellular } \\
\text { organismal } \\
\text { development }\end{array}$ & $\begin{array}{l}\text { DNA } \\
\text { binding; } \\
\text { Methyl-CpG } \\
\text { binding }\end{array}$ \\
\hline
\end{tabular}

(Continued) 


\begin{tabular}{|c|c|c|c|c|c|c|c|c|}
\hline Acc.nb & $\begin{array}{l}\text { Gene } \\
\text { name }\end{array}$ & $\begin{array}{l}\text { Protein } \\
\text { name }\end{array}$ & $\begin{array}{l}\text { Phosphopeptide } \\
\text { sequence }\end{array}$ & $\begin{array}{l}\text { Bry }^{+} \text {Flk-: } \\
\text { Bry-Flk- }\end{array}$ & $\begin{array}{l}\text { Bry }^{+} \text {Flk }^{+}: \\
\text {Bry }^{+} \text {Flk }\end{array}$ & $\begin{array}{l}\text { Bry }^{+} \text {Flk }^{+}: \\
\text {Bry-Flk }\end{array}$ & $\begin{array}{c}\text { GO Biological } \\
\text { Process }\end{array}$ & $\begin{array}{c}\text { GO } \\
\text { Molecular } \\
\text { Function }\end{array}$ \\
\hline P60904 & Dnajc5 & $\begin{array}{l}\text { DnaJ (Hsp40) } \\
\text { homolog, } \\
\text { subfamily C, } \\
\text { member } 5\end{array}$ & $\begin{array}{l}\text { SLpSTSGESL } \\
\text { YHVLGLDK }\end{array}$ & 1.35 & 1.11 & 1.51 & $\begin{array}{l}\text { Protein folding; } \\
\text { Negative } \\
\text { regulation } \\
\text { of neuron } \\
\text { apoptosis }\end{array}$ & $\begin{array}{l}\text { ATP- } \\
\text { dependent } \\
\text { protein } \\
\text { binding; Heat } \\
\text { shock protein } \\
\text { binding; } \\
\text { Unfolded } \\
\text { protein } \\
\text { binding }\end{array}$ \\
\hline Q8K310 & Matr3 & Matrin-3 & $\begin{array}{l}\text { TEpSPAE } \\
\text { GKEQEEK }\end{array}$ & 0.49 & 1.16 & 0.58 & Unannotated & $\begin{array}{l}\text { Nucleic acid } \\
\text { binding }\end{array}$ \\
\hline Q9Z1Q9 & Vars & $\begin{array}{l}\text { Valyl-tRNA } \\
\text { synthetase }\end{array}$ & $\begin{array}{l}\text { LpSATVTEAF } \\
\text { VRLHEEGVI }\end{array}$ & 1.44 & 0.56 & 0.79 & $\begin{array}{l}\text { tRNA } \\
\text { aminoacylation } \\
\text { for protein } \\
\text { translation }\end{array}$ & $\begin{array}{l}\text { Aminoacyl- } \\
\text { tRNA ligase } \\
\text { activity; } \\
\text { Nucleotide } \\
\text { binding }\end{array}$ \\
\hline Q80XU3 & Nucks1 & $\begin{array}{l}\text { Nuclear } \\
\text { ubiquitous casein } \\
\text { and cdk substrate }\end{array}$ & $\begin{array}{l}\text { ATVTP } \\
\text { pSPVKGK }\end{array}$ & 0.56 & 0.85 & 0.47 & Unannotated & DNA binding \\
\hline Q6PR54 & Rif1 & $\begin{array}{l}\text { Rap1-interacting } \\
\text { factor } 1\end{array}$ & $\begin{array}{l}\text { SSDpSVD } \\
\text { IEEQEEK }\end{array}$ & 0.69 & 0.58 & 0.37 & $\begin{array}{l}\text { Stem cell } \\
\text { maintenance; } \\
\text { cell cycle; } \\
\text { Response to } \\
\text { DNA damage } \\
\text { stimulus }\end{array}$ & $\begin{array}{l}\text { Protein } \\
\text { binding }\end{array}$ \\
\hline Q6PR54 & Rif1 & $\begin{array}{l}\text { Rap1-interacting } \\
\text { factor } 1\end{array}$ & $\begin{array}{l}\text { VSDSSL } \\
\text { pSPEK }\end{array}$ & 0.84 & 0.64 & 0.53 & $\begin{array}{l}\text { Stem cell } \\
\text { maintenance; cell } \\
\text { cycle; Response } \\
\text { to DNA damage } \\
\text { stimulus }\end{array}$ & $\begin{array}{l}\text { Protein } \\
\text { binding }\end{array}$ \\
\hline Q8CBW3 & Abil & Abl interactor 1 & $\begin{array}{l}\text { TNPPTQKPP } \\
\text { SPPVpSGR }\end{array}$ & 0.99 & 1.67 & 1.64 & $\begin{array}{l}\text { Peptidyl- } \\
\text { tyrosine } \\
\text { phosphorylation; } \\
\text { Cell motility }\end{array}$ & $\begin{array}{l}\text { Protein } \\
\text { binding; } \\
\text { Protein } \\
\text { tyrosine } \\
\text { kinase } \\
\text { activator } \\
\text { activity }\end{array}$ \\
\hline Q08943 & Ssrp1 & $\begin{array}{l}\text { FACT complex } \\
\text { subunit SSRP1 }\end{array}$ & $\begin{array}{l}\text { EGINPGYD } \\
\text { DYADpSDE } \\
\text { DQHDAYLER }\end{array}$ & 1.56 & 0.68 & 1.05 & $\begin{array}{l}\text { Regulation of } \\
\text { transcription, } \\
\text { DNA-dependent }\end{array}$ & DNA binding \\
\hline Q64012 & Raly & $\begin{array}{l}\text { hnRNP-associated } \\
\text { with lethal yellow }\end{array}$ & GRLpSPVPVPR & 2.53 & 0.47 & 1.37 & $\begin{array}{l}\text { RNA splicing; } \\
\text { mRNA } \\
\text { processing }\end{array}$ & RNA binding \\
\hline Q9JIX8 & Acin 1 & Acinus & $\begin{array}{l}\text { HLpSHPEP } \\
\text { EQQHVIQR }\end{array}$ & 1.15 & 0.52 & 0.59 & $\begin{array}{l}\text { Apoptosis; } \\
\text { Apoptotic } \\
\text { chromosome } \\
\text { condensation }\end{array}$ & $\begin{array}{l}\text { Nucleic acid } \\
\text { binding; } \\
\text { Nucleotide } \\
\text { binding }\end{array}$ \\
\hline P11499 & $\begin{array}{l}\text { Hsp } \\
90 \mathrm{ab} 1\end{array}$ & $\begin{array}{l}\text { Heat-shock } \\
\text { protein hsp84 }\end{array}$ & $\begin{array}{l}\text { IEDVGpSDE } \\
\text { EDDSGKDK }\end{array}$ & 0.55 & 1.35 & 0.73 & $\begin{array}{l}\text { Protein folding; } \\
\text { Response to } \\
\text { stress; Placenta } \\
\text { development }\end{array}$ & $\begin{array}{l}\text { Protein } \\
\text { binding }\end{array}$ \\
\hline
\end{tabular}

(Continued) 


\begin{tabular}{|c|c|c|c|c|c|c|c|c|}
\hline Acc.nb & $\begin{array}{l}\text { Gene } \\
\text { name }\end{array}$ & $\begin{array}{l}\text { Protein } \\
\text { name }\end{array}$ & $\begin{array}{c}\text { Phosphopeptide } \\
\text { sequence }\end{array}$ & $\begin{array}{l}\text { Bry }^{+} \text {Flk-: } \\
\text { Bry-Flk- }\end{array}$ & $\begin{array}{l}\text { Bry }^{+} \text {Flk }^{+}: \\
\text {Bry }^{+} \text {Flk }\end{array}$ & $\begin{array}{l}\text { Bry }^{+} \text {Flk }^{+}: \\
\text {Bry-Flk }\end{array}$ & $\begin{array}{c}\text { GO Biological } \\
\text { Process }\end{array}$ & $\begin{array}{c}\text { GO } \\
\text { Molecular } \\
\text { Function }\end{array}$ \\
\hline P42208 & Sept2 & $\begin{array}{l}\text { Septin } 2 \text { (NEDD5 } \\
\text { protein) }\end{array}$ & $\begin{array}{l}\text { IYHLPDAE } \\
\text { pSDEDE } \\
\text { DFKEQTR }\end{array}$ & 1.01 & 1.68 & 1.69 & Cell cycle & $\begin{array}{l}\text { GTPase } \\
\text { activity; } \\
\text { Protein } \\
\text { binding }\end{array}$ \\
\hline O54839 & Eomes & Eomes & $\begin{array}{l}\text { KGpSPC } \\
\text { AEEELPS } \\
\text { AATAAATAR }\end{array}$ & 1.52 & 0.76 & 1.15 & $\begin{array}{l}\text { Blastocyst } \\
\text { development; } \\
\text { Multicellular } \\
\text { organismal } \\
\text { development; } \\
\text { Stem cell } \\
\text { maintenance; } \\
\text { Mesoderm } \\
\text { formation; } \\
\text { Endoderm } \\
\text { formation; } \\
\text { Interferon- } \\
\text { gamma } \\
\text { production }\end{array}$ & $\begin{array}{l} \\
\text { DNA } \\
\text { binding; } \\
\text { Transcription } \\
\text { factor } \\
\text { activity }\end{array}$ \\
\hline Q9CW46 & Raver1 & $\begin{array}{l}\text { Ribonucleoprotein } \\
\text { PTB-binding } 1\end{array}$ & LLpSPIASNR & 1.33 & 0.49 & 0.65 & Unannotated & RNA binding \\
\hline Q6P4S8 & Ints1 & $\begin{array}{l}\text { Integrator } \\
\text { complex subunit } 1\end{array}$ & $\begin{array}{l}\text { LSpSTP } \\
\text { PLSALGR }\end{array}$ & 2.45 & 0.66 & 1.62 & $\begin{array}{l}\text { snRNA } \\
\text { processing; } \\
\text { Blastocyst } \\
\text { growth; Inner } \\
\text { cell mass cell } \\
\text { proliferation; } \\
\text { Apoptosis }\end{array}$ & Unannotated \\
\hline Q8CGU3 & Pnn & Pinin & $\begin{array}{l}\text { RGFpSD } \\
\text { SGGGPPAK }\end{array}$ & 1.26 & 1.37 & 1.71 & $\begin{array}{l}\text { Cell-cell } \\
\text { adhesion; } \\
\text { Regulation of } \\
\text { transcription, } \\
\text { DNA- } \\
\text { dependent; RNA } \\
\text { splicing; mRNA } \\
\text { processing }\end{array}$ & DNA binding \\
\hline
\end{tabular}

To be considered as changing, a phosphopeptide should have a ratio outside the range in which 95\% of phosphopeptides ratios for the internal control replicates are found. Phosphopeptides shown are those where a confident assessment of a significant decrease or increase was found. To be included the data must have a -fold change $<0.6$ or $>1.5$ with a $p$ value of less than 0.05. The significant changes are shown in bold; the underlined values represent changes where the confidence levels were not met. Every spectrum has been manually checked to verify phosphorylation. The first three columns report the Accession Number (UniProtKB-SwissProt), the Gene and Protein name, and the primary sequence of the phosphopeptide identified, indicating in bold the aminoacid modified by phosphorylation and in brackets the phosphosite position in the full length protein. The next three columns report the $\log (2)$ of the iTRAQ ratios representing the changes in phosphorylation level occurring during the progression of the hematopoietic differentiation, comparing Bry ${ }^{+} \mathrm{Flk} 1^{-}: \mathrm{Bry}^{-} \mathrm{Flk} 1^{-}, \mathrm{Bry}^{+} \mathrm{Flk} 1^{+}: \mathrm{Bry}^{+} \mathrm{Flk} 1^{-}$ and $\mathrm{Bry}^{+} \mathrm{Flk} 1^{+}$:Bry${ }^{-} \mathrm{Flk1}{ }^{-}$. The last two columns show the Biological process and Molecular function classification for the reported phosphopeptide-derived proteins, according to the Gene Ontology annotations. Data from two independent biological replicate were merged into the table.

12 phosphoentities down-regulated; in the hemangioblast 10 phosphoentities were up-regulated and 16 phosphoentities down-regulated.

We focused the data analysis on early phosphorylative changes, occurring in the first stages of the differentiation process, proceeding from the epiblast to the early mesoderm cells $\left(\mathrm{Bry}^{+} \mathrm{Flk1}^{-}\right.$and $\left.\mathrm{Bry}^{-} \mathrm{Flk}^{-}\right)$, and those which are differentially regulated in the BL-CFC cells $\left(\mathrm{Bry}^{+} \mathrm{Flk} 1^{+}\right)$. According to this analysis, phosphopeptides can be divided into 3 groups. Group 1: phosphopeptides up- or downregulated during early mesoderm differentiation. Group 2: phosphopeptides up- or down-regulated in BL-CFC cells. 
Table 2: Phosphosite retrieved informations based on mass spectrometry identification and esperimental evidences.

\begin{tabular}{|c|c|c|c|c|c|c|c|}
\hline Acc.nb & $\begin{array}{l}\text { Gene } \\
\text { name }\end{array}$ & Protein name & $\begin{array}{l}\text { Phosphopeptide } \\
\text { sequence }\end{array}$ & $\begin{array}{l}\text { (P)site } \\
\text { position }\end{array}$ & $\begin{array}{c}\text { MS } \\
\text { evidence }\end{array}$ & $\begin{array}{c}\text { EX } \\
\text { evidence }\end{array}$ & $\begin{array}{c}\text { Protein } \\
\text { kinase }\end{array}$ \\
\hline P57776 & Eefld & eEF1d protein & $\begin{array}{l}\text { GATPAEDDED } \\
\text { KDIDLFGpSD } \\
\text { EEEEDKEAAR }\end{array}$ & S162 & $\mathrm{Y}$ & Y & CK2 \\
\hline P57776 & Eefld & eEF1d protein & $\begin{array}{l}\text { ATAPQTQ } \\
\text { HVpSPMR }\end{array}$ & S133 & $\mathrm{Y}$ & Y & Cdc2 \\
\hline Q6J1H4 & Utf1 & UTF1 & $\begin{array}{l}\text { RLPAFSPP } \\
\text { SPApSPDAELR }\end{array}$ & S18 & $\mathrm{Y}$ & $\mathrm{N}$ & \\
\hline Q6J1H4 & Utf1 & UTF1 & $\begin{array}{l}\text { RLPAFpSP } \\
\text { PSPApSPDAELR }\end{array}$ & S12, S18 & $\mathrm{Y}$ & $\mathrm{N}$ & \\
\hline Q6J1H4 & Utfl & UTF1 & $\begin{array}{l}\text { RLPAFSPP } \\
\text { pSPASPDAELR }\end{array}$ & S15 & $\mathrm{Y}$ & $\mathrm{N}$ & \\
\hline Q6J1H4 & Utf1 & UTF1 & $\begin{array}{l}\text { RLPAFSPP } \\
\text { pSPApSPDAELR }\end{array}$ & S15, S18 & $\mathrm{Y}$ & $\mathrm{N}$ & \\
\hline Q6J1H4 & Utf1 & UTF1 & $\begin{array}{l}\text { SAGDVPVT } \\
\text { TSDAFATS } \\
\text { GGMAEPGpSPK }\end{array}$ & S48 & $\mathrm{Y}$ & $\mathrm{N}$ & \\
\hline P17095 & Hmgal & $\begin{array}{l}\text { High mobility group } \\
\text { protein HMG-I/ } \\
\text { HMG-Y }\end{array}$ & $\begin{array}{l}\text { KQPPV } \\
\text { pSPGTALVGSQK }\end{array}$ & S36 & $\mathrm{Y}$ & Y & $\begin{array}{l}\text { CDK2, } \\
\text { HIPK2 }\end{array}$ \\
\hline P52927 & Hmga2 & $\begin{array}{l}\text { High mobility group } \\
\text { protein HMG-A2 }\end{array}$ & \begin{tabular}{|l} 
KQQQEPT \\
CEPpSPKRPR
\end{tabular} & S44 & $\mathrm{Y}$ & Y & Cdc2 \\
\hline Q9CQS8 & Sec61b & Sec61 beta subunit & $\begin{array}{l}\text { PGPTPSGTN } \\
\text { VGSpSGRSPSK }\end{array}$ & S14 & Y & $\mathrm{N}$ & \\
\hline Q9CQS8 & Sec61b & Sec61 beta subunit & $\begin{array}{l}\text { PGPTPSGTN } \\
\text { VGSSGRpSPSK }\end{array}$ & S17 & Y & $\mathrm{N}$ & \\
\hline P30999 & Ctnnd1 & $\begin{array}{l}\text { Catenin delta-1 (p120 } \\
\text { catenin) }\end{array}$ & GSLApSLDSLRK & S346 & $\mathrm{Y}$ & $\mathrm{N}$ & \\
\hline Q8K019 & Bclaf1 & $\begin{array}{l}\text { Bcl-2-associated } \\
\text { transcription factor }\end{array}$ & IDIpSPSALRK & S656 & Y & $\mathrm{N}$ & \\
\hline Q9WV60 & Gsk3b & $\begin{array}{l}\text { Glycogen synthase } \\
\text { kinase } 3 b\end{array}$ & GEPNVpSYICSR & S215 & $\mathrm{Y}$ & $\mathrm{N}$ & \\
\hline O88509 & Dnmt3b & $\begin{array}{l}\text { DNA (cytosine-5) } \\
\text { methyltransferase 3B }\end{array}$ & $\begin{array}{l}\text { TTNDSAASE } \\
\text { pSPPPKR }\end{array}$ & S399 & $\mathrm{Y}$ & $\mathrm{N}$ & \\
\hline Q01320 & Top2a & $\begin{array}{l}\text { Topoisomerase } \\
\text { (DNA) II alpha }\end{array}$ & $\begin{array}{l}\text { KPIKYLEE } \\
\text { pSDDDDDLF }\end{array}$ & S1521 & Y & Y & $\begin{array}{l}\text { PLK1, } \\
\text { CK2 }\end{array}$ \\
\hline P14733 & Lmnb1 & Lamin B1 & LKLpSPSPSSR & S392 & $\mathrm{Y}$ & $\mathrm{N}$ & \\
\hline Q8BTI8 & Srrm2 & $\begin{array}{l}\text { Serine/arginine } \\
\text { repetitive matrix } 2\end{array}$ & $\begin{array}{l}\text { MVQASSQSLLP } \\
\text { PAQDRPRpSP } \\
\text { VPSAFSDQSR }\end{array}$ & S2404 & Y & $\mathrm{N}$ & \\
\hline Q569Z6 & Thrap3 & $\begin{array}{l}\text { Thyroid hormone } \\
\text { receptor associated } \\
\text { protein } 3\end{array}$ & RIDIpSPSTFR & S679 & $\mathrm{Y}$ & $\mathrm{N}$ & \\
\hline P97496 & Smarcc1 & $\begin{array}{l}\text { SWI/SNF complex } \\
155 \mathrm{kDa} \text { subunit }\end{array}$ & $\begin{array}{l}\text { RKPpSPpSP } \\
\text { PPPTATESR }\end{array}$ & S327, S329 & Y & $\mathrm{N}$ & \\
\hline
\end{tabular}

(Continued) 


\begin{tabular}{|c|c|c|c|c|c|c|c|}
\hline Acc.nb & $\begin{array}{l}\text { Gene } \\
\text { name }\end{array}$ & Protein name & $\begin{array}{c}\text { Phosphopeptide } \\
\text { sequence }\end{array}$ & $\begin{array}{l}\text { (P)site } \\
\text { position }\end{array}$ & $\begin{array}{c}\text { MS } \\
\text { evidence }\end{array}$ & $\begin{array}{c}\text { EX } \\
\text { evidence }\end{array}$ & $\begin{array}{l}\text { Protein } \\
\text { kinase }\end{array}$ \\
\hline Q8VDF2 & Uhrf1 & $\begin{array}{l}\text { E3 ubiquitin-protein } \\
\text { ligase UHRF1 }\end{array}$ & $\begin{array}{l}\text { RPLIApSPS } \\
\text { QPPPALR }\end{array}$ & S289 & $\mathrm{Y}$ & $\mathrm{N}$ & \\
\hline P60904 & Dnajc5 & $\begin{array}{l}\text { DnaJ (Hsp40) } \\
\text { homolog, subfamily } \\
\text { C, member } 5\end{array}$ & $\begin{array}{l}\text { SLpSTSGES } \\
\text { LYHVLGLDK }\end{array}$ & S10 & $\mathrm{Y}$ & $\mathrm{Y}$ & AKT \\
\hline Q8K310 & Matr3 & Matrin-3 & TEpSPAEGKEQEEK & S619 & Y & $\mathrm{N}$ & \\
\hline Q9Z1Q9 & Vars & $\begin{array}{l}\text { Valyl-tRNA } \\
\text { synthetase }\end{array}$ & $\begin{array}{l}\text { LpSATVTEA } \\
\text { FVRLHEEGVI }\end{array}$ & N.R. & $\mathrm{N}$ & $\mathrm{N}$ & \\
\hline Q80XU3 & Nucks1 & $\begin{array}{l}\text { Nuclear ubiquitous } \\
\text { casein and cdk } \\
\text { substrate }\end{array}$ & ATVTPpSPVKGK & S181 & $\mathrm{Y}$ & $\mathrm{Y}$ & CDK2 \\
\hline Q6PR54 & Rif1 & $\begin{array}{l}\text { Rap1-interacting } \\
\text { factor } 1\end{array}$ & SSDpSVDIEEQEEK & S1565 & $\mathrm{Y}$ & $\mathrm{N}$ & \\
\hline Q6PR54 & Rif1 & $\begin{array}{l}\text { Rap1-interacting } \\
\text { factor } 1\end{array}$ & VSDSSLpSPEK & S1683 & Y & $\mathrm{N}$ & \\
\hline Q8CBW3 & Abil & Abl interactor 1 & $\begin{array}{l}\text { TNPPTQKPP } \\
\text { SPPVpSGR }\end{array}$ & S187 & $\mathrm{Y}$ & $\mathrm{N}$ & \\
\hline Q08943 & Ssrp1 & $\begin{array}{l}\text { FACT complex } \\
\text { subunit SSRP1 }\end{array}$ & $\begin{array}{l}\text { EGINPGYDD } \\
\text { YADpSDED } \\
\text { QHDAYLER }\end{array}$ & S444 & $\mathrm{Y}$ & $\mathrm{N}$ & \\
\hline Q64012 & Raly & $\begin{array}{l}\text { hnRNP-associated } \\
\text { with lethal yellow }\end{array}$ & GRLpSPVPVPR & S135 & Y & $\mathrm{Y}$ & CDK2 \\
\hline Q9JIX8 & Acin 1 & Acinus & HLpSHPEPEQQHVIQR & S710 & $\mathrm{Y}$ & $\mathrm{N}$ & \\
\hline P11499 & Hsp90ab1 & $\begin{array}{l}\text { Heat-shock protein } \\
\text { hsp84 }\end{array}$ & $\begin{array}{l}\text { IEDVG } \\
\text { pSDEEDDSGKDK }\end{array}$ & S255 & $\mathrm{Y}$ & Y & $\begin{array}{l}\text { TK, } \\
\text { CK2 }\end{array}$ \\
\hline P42208 & Sept2 & $\begin{array}{l}\text { Septin } 2 \text { (NEDD5 } \\
\text { protein) }\end{array}$ & $\begin{array}{l}\text { IYHLPDAE } \\
\text { pSDEDEDFKEQTR }\end{array}$ & S218 & $\mathrm{Y}$ & $\mathrm{Y}$ & \\
\hline O54839 & Eomes & Eomes & $\begin{array}{l}\text { KGpSPCAEE } \\
\text { ELPSAATAAATAR }\end{array}$ & S117 & $\mathrm{Y}$ & $\mathrm{N}$ & \\
\hline Q9CW46 & Raver1 & $\begin{array}{l}\text { Ribonucleoprotein } \\
\text { PTB-binding 1 }\end{array}$ & LLpSPIASNR & S576 & $\mathrm{Y}$ & $\mathrm{N}$ & \\
\hline Q6P4S8 & Ints1 & $\begin{array}{l}\text { Integrator complex } \\
\text { subunit } 1\end{array}$ & LSpSTPPLSALGR & S82 & $\mathrm{Y}$ & $\mathrm{N}$ & \\
\hline Q8CGU3 & Pnn & Pinin & RGFpSDSGGGPPAK & S66 & Y & $\mathrm{N}$ & \\
\hline
\end{tabular}

The first three columns report the Accession Number (UniProtKB-SwissProt), the Gene and Protein name, and the primary sequence of the phosphopeptide identified, indicating in bold the aminoacid modified by phosphorylation and in brackets the phosphosite position in the full length protein. The next three columns report the phosphosite position with respect to the protein primary sequence, whether the site has been identified by mass-spectrometry based methods (MS evidence) and experimental methods (EX evidence). $\mathrm{Y}=\mathrm{yes}, \mathrm{N}=$ no. These informations were retrieved from PhosphositePlus; experimental methods include aminoacid sequencing, site-directed mutagenesis, modification site-specific antibodies and targeted MS strategies. The last column report the protein kinase responsible for the specific site phosphorylation, identified by EX evidences.

Group 3: phosphopeptides changing neither in BryFlk1', $\mathrm{Bry}^{+} \mathrm{Flk1}^{-}$nor Bry ${ }^{+} \mathrm{Flk} 1^{+}$. Interestingly, almost half of the phosphopeptides that were differentially regulated in the ${ }^{B r y}{ }^{+} \mathrm{Flk}^{-}$and Bry Flk1 ${ }^{-}$, were not changing in the Bry ${ }^{+} \mathrm{Flk} 1^{+}$ and vice versa. Only phosphopeptides emanated from Efld and Ints1 were up-regulated either in the progression from Bry Flk $1^{-}$to Bry ${ }^{+} \mathrm{Flk1} 1^{-}$and in the Bry ${ }^{+} \mathrm{Flk1} 1^{+}$; Utf1, Dnmt3b, Srrm2 Thrap3, Matr3 and Nucks1 phosphopeptides were instead down-regulated in both stages. Only phosphopeptides belonging to the proteins Hmgal, Vars and Raver1 
were neither changing in the progression Bry-Flk1- to $\mathrm{Bry}^{+} \mathrm{Flk}^{-}$and in the hemangioblast cells, indicating that post-translational regulation involving these proteins may be fundamental for the transition from the Bry ${ }^{+} \mathrm{Flk} 1^{-}$to Bry $^{+} \mathrm{Flk}^{+}$.

\section{The regulation of consequential temporal processes, by means of phosphorylation, governed the hemangioblast development}

Comparing the phosphopeptides changing in $\mathrm{Bry}^{+} \mathrm{Flk} 1^{+}$and those which occur in the very early steps of differentiation, according to the Gene Ontology, different categories of biological processes were involved (Figure 2). Proteins involved in regulation of cell differentiation and gene expression, developmental processes and especially embryonic development, such as Ints1, Top2a, Dnmt3b and Gsk3b, Utf1, Bclaf1, Thrap3 and Ssrp1, were found to be differentially phosphorylated in all the three stages of ES cells differentiation (Figure 2A and 2C). Phosphorylation on Ints 1 and Dnmt3b was regulated the same in Bry ${ }^{+} \mathrm{Flk} 1^{-}$ :Bry-Flk1 ${ }^{-}$and Bry $^{+} \mathrm{Flk1}^{+}$:Bry ${ }^{-} \mathrm{Flk}^{-}$; Top2a decreased in Bry $^{+} \mathrm{Flk1}^{-}: \mathrm{Bry}^{-} \mathrm{Flk1} 1^{-}$, but it didn't change in the Bry ${ }^{+} \mathrm{Flk} 1^{+}$ while Gsk3b phosphorylation decreased as cells started to differentiate, then progressively increased as cells became $\mathrm{Bry}^{+} \mathrm{Flk} 1^{+}$.

However, as expected, there are processing taking place in a consequential temporal pattern. As mES cells started to differentiate, phosphopeptides significantly changing were emanated from proteins involved in blastocyst and placenta development, the formation of the primary germ layer and mesoderm; such as Eomes, Hsp90ab1, Smarcc1 and Gsk3b. Conversely, as the BLCFC cells were formed, differentially phosphorylated peptides emanated from proteins involved in cell cycle, cell division and mRNA processing such as Uhrfl, Sept2, Rif1, Hmga2, Srrm2 and Pnn; in the regulation of phosphorylation and kinase activity, such as the Wnt
A

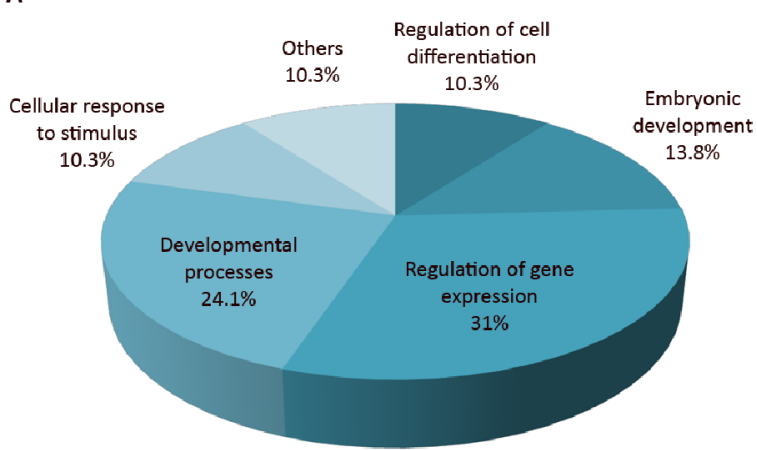

B

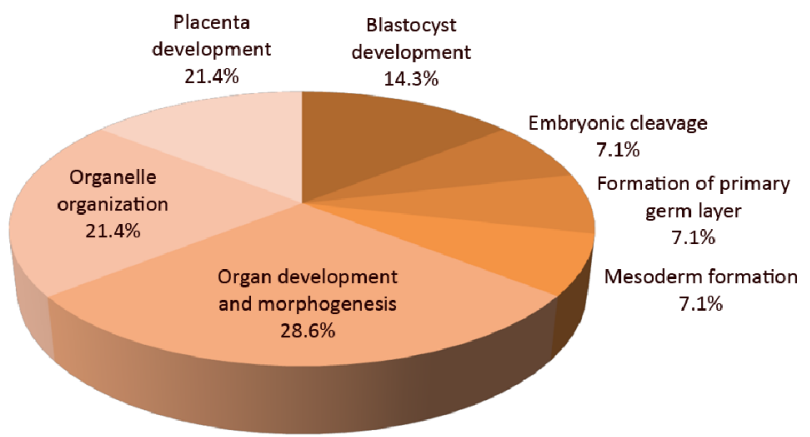

Group1:

up- or down-regulated in BryFlk and Bry'Flk

C

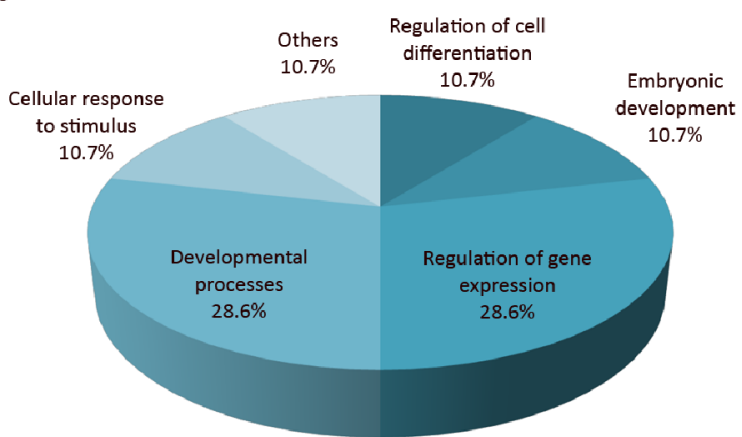

D

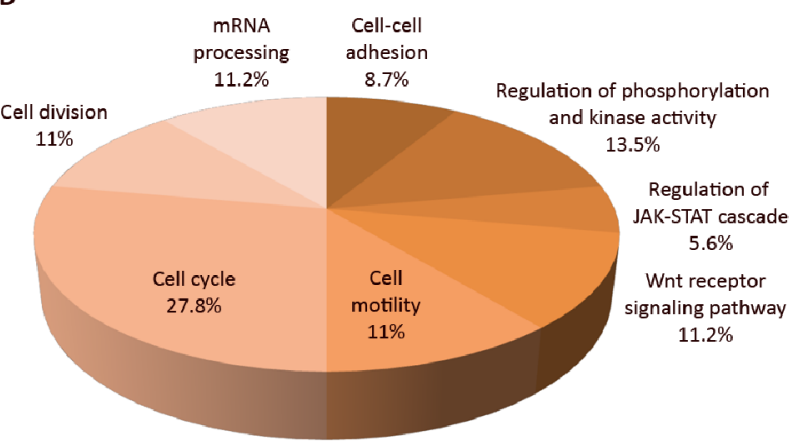

Group2:

up- or down-regulated in Bry ${ }^{+} \mathrm{Flk}^{+}$

Figure 2: Biological classification of differentially regulated phosphopeptides.. Pie chart representation of the phosphopeptideemanated proteins classified into groups by Biological process. Phosphopeptides from Group 1 (up- or down-regulated in Bry-Flk1 ${ }^{-}$and $\mathrm{Bry}^{+} \mathrm{Flk} 1^{-}$) and Group 2 (up- or down-regulated in Bry ${ }^{+} \mathrm{Flk} 1^{+}$) were considered as they are indicative for the regulation of stem cell differentiation. The relative frequency of over-represented categories is reported as percentage in the pie charts. (A) and (C) Biological processes of phosphopeptides differentially regulated both in Group 1 and Group 2, respectively. (B) and (D) Biological processes specific to phosphopeptides differentially regulated either in Group 1 or Group 2. Gene Ontology classification was performed using the plugin BiNGO v2.42 within Cytoscape v.2.8.2, assessing over-represented categories with a hypergeometric statistical test and Benjamini \& Hochberg False Discovery Rate correction $(p<0.05)$. As a reference set, the whole mouse repository annotation was used. 
receptor signaling pathway (Ctnnd1 and Abi1) and the JAK-STAT cascade (Hmga2). Notably, few proteins also had a role in cell-cell adhesion and cell motility, such as Ctnnd1, Pnn and Rif1.

\section{Comparison with expression dataset}

Twenty-one phosphopeptides within this dataset were found to emanate from proteins analyzed in the nuclear proteome expression analysis associated with Bry and Flk1 expression previously published [4] (Figure 3). Although the expression of the proteins did not change during hematopoietic differentiation, 9 phosphopeptides displayed differential regulation: Hmga1, Sec61b, Ctnnd1, Gsk3b, Dnajc5, Nucks1, Rif1, Ssrp1, Raver1. Among these, phosphorylation on Hmgal and Raverl only decreased in the progression from $\mathrm{Bry}^{+} \mathrm{Flk} 1^{-}$to $\mathrm{Bry}^{+} \mathrm{Flk} 1^{+}$; while Raver1 is involved in the regulation of alternative splicing [21], Hmgal plays a role in modulation of gene expression during development and embryogenesis, and its expression is known to be markedly diminished in differentiated cells [22]. Interestingly, Ctnnd1, Gsk3 and Rif1, are involved either in the regulation of cell differentiation and developmental processes, but also in the regulation of the cellular response to signaling pathways, such as the Wnt receptor signaling pathway. Moreover, GSK3 was found to play a pivotal role in controlling the decision fate of ES cells between selfrenewal and differentiation; in fact inhibition of GSK3 has been found to promote and maintain mESC self-renewal [23]. As shown in Figure 3, in the majority of the cases normalization against protein level revealed no protein level change modulating stoichiometry of phosphorylation. For example, Hmga2 expression was augmented as ES cells differentiate and it remains high in the $\mathrm{Bry}^{+} \mathrm{Flk} 1^{+}$: we found a peptide whose phosphorylation increased as mES cells differentiate, and this phosphorylation is maintained in the $\mathrm{Bry}^{+} \mathrm{Flk} 1^{+}$population. Hmga2 can exert a negative regulation on the Jak-Stat signaling cascade [24]. The Jak/Stat pathway promotes ESCs self-renewal [25] and is required for self-renewal of Drosophila sperm stem cells [26]. Conversely, only few phosphopeptides did not exhibit a correspondence between phosphorylation and protein expression. Among these, is the phosphopeptide emanating from the chromatin remodeling factor Smarcc1/ Baf155, whose phosphorylation increased as mESCs differentiated toward mesoderm lineage commitment. Interestingly, Schaniel et co-workers [27], showed that Smarcc1 plays a balance between gene repression, which maintains ESCs in the self-renewal state and chromatin rearrangements, that led to the expression of genes involved in differentiation.

\section{DISCUSSION}

Phosphoproteomic data can be a powerful tool to broaden understand of ES cells and how their ultimate fate is determined. Many transcription regulators such as epigenetic and transcription factors, as well as a large number of kinases are phosphorylated in embryonic stem cells [18-28, 29], suggesting that these post-translational modifications play a key role in determining stem cell fate. Our study reported the identification of novel phosphosites within proteins involved in ES cell mesoderm differentiation and the relative quantification of the phosphorylation stoichiometry during the progression from epiblast-like cells to the hemangioblast (BL-CFC cells).

The Gene Ontology classification highlighted that different biological processes play a role during the mesoderm-induced mESCs differentiation. During differentiation, phosphopeptides emanated from proteins involved in embryonic development were identified. In the last stage, when the hemangioblast is formed, phosphorylation differentially influences proteins involved in cell cycle, regulation of transcription and signaling pathways, indicating that mass spectrometry and phosphoproteomic analysis identified key modulators of the development process toward blood. For example, we reported a phosphopeptide emanated from Uhrf1 (also called Np95), which is known to contain a cyclin $\mathrm{A} / \mathrm{E}-\mathrm{Cdk} 2$ phosphorylation site. It has been demonstrated not only that Uhrf1 is essential for maintaining genomic methylation in embryonic stem cells by recruiting DNA methyltransferase (Dnmt) 1 to hemi-methylated CpG sites generated during replication [30], but also to interact with de novo methyltransferases Dnmt3a and Dnmt3b, mediating promoter silencing before DNA methylation is detected [31]. Uhtf1 is also involved in the regulation of Top $2 \mathrm{a}$. It has been suggested that Uhrf1 regulates transcription of Top 2 a by binding to an inverted 5'-CCAAT-3' box in the Top2a promoter and activating expression [32]. Moreover it has been established that Uhfr1 contributes to genomic stability functioning in the response pathways against DNA damage and replication arrest [33]. Phosphopeptides emanated from both Top2a and Dnmt3b were found within our dataset.

Of particular interest was the identification of a phosphopeptide emanated from GSK3b, which phosphorylation increases as stem cells differentiate. GSK3b activity has been demonstrated to be crucial for the switch between stem cell self-renewal and differentiation. The regulation of GSK3 activity is able to inhibit self-renewal and promote differentiation [34]. But GSK3 functions in a wide range of cellular processes and it can both act as a tumor suppressor and as oncogene, in the development of various human cancers [35-37]. Of the phosphopetide emanated proteins within our dataset, 7 proteins present with at least 1 potential site that can be phosphorylated by GSK3b with high stringency (http://scansite3.mit.edu) (Acin1, Blacf1, Dnmt3b, 


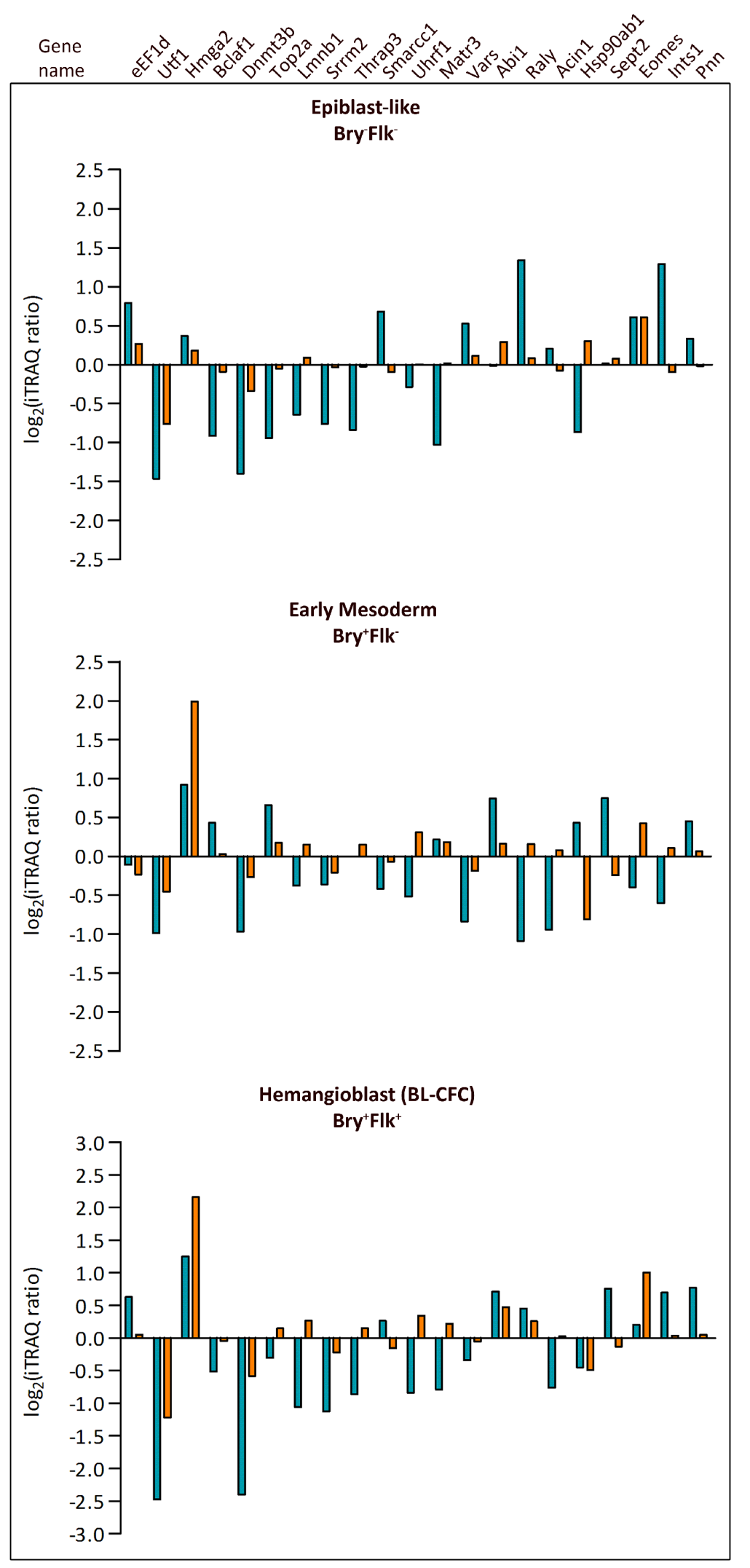

Figure 3: Comparison between phosphopeptides and protein expression levels. Panels show changes in identified phosphopeptides compared to the expression profile of the referring proteins previously identified [4]. Blue histograms represent phosphorylation and orange histograms refer to protein expression level changes in Bry-Flk1- (Epiblast-like cells), Bry ${ }^{+}$Flk1 ${ }^{-}($Early mesoderm) and Bry ${ }^{+} \mathrm{Flk} 1^{+}$(Hemangioblast). 
Pnn, Rif1, Srrm2, Thrap3). Only 1 of the phosphopeptides identified contain the putative GSK3b consensus sequence (Abi1, medium stringency).

Another interesting protein was the Smarcc1/ Baf155, that we found to be phosphorylated on S327 and S329; the phosphorylation of this doubly phosphorylated peptide decreased as stem cells differentiate toward the mesoderm commitment. Smarcc1/Baf155 belongs to the SWI/SNF multiprotein chromatin remodeling complex, and is required for heterochromatin formation and chromatin condensation during differentiation. In human ES cells, Smarcc1/Baf155 plays a dual role in maintaining pluripotency: it can promote or repress selfrenewal gene expression, e.g. Nanog [38]. Furthermore, the SWI/SNF chromatin-remodeling complex also promotes somatic cell reprogramming by facilitating Oct4 binding to its target promoters. In retinoic acidmediated differentiation, Baf155 can integrate p53 function to regulate ectodermal and mesodermal gene expression [27]. The possibility of Aurka-mediated p53 phosphorylation altering the interaction between p53 and the SWI/SNF complex as well as other epigenetic regulatory complexes is particularly tantalizing and may, in part, explain the apparent paradoxical requirement for SWI/SNF in both ESC maintenance and differentiation. As in silico analysis suggests (http://scansite3.mit.edu), Erk1 might be the kinase deputated to phosphorylate S327 and S329. Recently, Erk1/2, as GSK3b, was found to promote self-renewal, maintaining cellular growth capacity and reinforcing suppression of commitment [39-40].

We are only beginning to understand the molecular and cellular mechanisms of normal hematopoietic development and many pieces of these puzzle are still missing. The in vitro differentiation of ES cells has been instrumental in the identification and characterization of the hemangioblast.

Understanding how blood cells are generated is important from a biological perspective but also has potential implications in the treatment of blood diseases. Searches for post-translational regulatory processes are likely to lead to the identification of new important players in blood specification than can be altered in blood cancers. Knowing how signaling molecules regulates, by phosphorylation, their downstream targets could represent a precise stem cell signaling process that can lead to blood cancers, if unregulated or disrupted.

\section{MATERIALS AND METHODS}

\section{Cell culture and differentiation}

The Bry ${ }^{+}$ES cell line was generated by Fehling et al. [3], introducing the GFP gene into one allele of the Bry (Brachyury) gene of the mouse embryonic stem cell line clone E14.1. ES cells were maintained and differentiated as previously described [3].

\section{Cell sorting flow cytometry}

EBs were harvested, trypsinized and the single cell suspension analyzed on a FacsCalibur flow cytometer (BD Bioscences). Staining and isolation of cell populations were performed as previously described [3]. The expression of Bry with the Flk1 receptor in a temporal pattern revealed the emergence of three distinct populations, Bry-Flk1-, $\mathrm{Bry}^{+} \mathrm{Flk1} 1^{-}, \mathrm{Bry}^{+} \mathrm{Flk1} 1^{+}$, which represented a developmental progression from epiblast-like to early mesoderm then BL-CFC cells [3]. These sorted populations were used for analysis of the phosphoproteome.

\section{Nuclear isolation}

Nuclear extraction was performed using the Nuclear Extract kit (Active Motif, Brussels, Belgium) as previously described [41]. Briefly, $1 \times 10^{7}$ cells from each sorted population were washed in ice cold Hanks buffer (136.7 mM NaCl, $5.35 \mathrm{mM} \mathrm{KCl}, 0.812 \mathrm{mM} \mathrm{MgSO}_{4}, 1.28$ $\mathrm{mM} \mathrm{CaCl}, 5.5 \mathrm{mM}$ Glucose, $24 \mathrm{mM}$ Hepes, $\mathrm{pH}$ 7.4) with phosphatase inhibitors and then lysed in hypotonic buffer, following the manufacturer's instructions. Nuclei were then lysed in $1 \mathrm{M}$ triethylammonium bicarbonate lysis buffer (TEAB, Sigma-Aldrich, St. Louis, MO), 0.05\% $(\mathrm{w} / \mathrm{v})$ SDS, protease inhibitor cocktail, phosphatase inhibitors and Benzonase (Novagen, UK). The protein concentration was determined using the Bradford protein assay (Bio-Rad, Hemel Hempstead, UK). The nuclear purity was assessed by Western Blot analysis for nuclear (lamin $\mathrm{a} / \mathrm{c}$ ) and cytoplasmic ( $\beta$-tubulin) markers.

\section{4-plex iTRAQ ${ }^{\mathrm{TM}}$ labeling}

An aliquot of $100 \mu \mathrm{g}$ of each nuclear protein sample was reduced, digested and labeled with four-channel iTRAQ ${ }^{\mathrm{TM}}$ reagent (Applied Biosystem, Framingham, MA) according with the manufacturer's instructions. As previously described [41], protein were reduced with 50 $\mathrm{mM}$ tris-(2-carboxyethyl)phosphine, then alkylated by adding $200 \mathrm{mM}$ methylmethanethiosulphate. Trypsin (5 $\mu \mathrm{g}, 0.5 \mu \mathrm{g} / \mu \mathrm{l}$, Promega) was added, and the samples were incubated overnight at $37^{\circ} \mathrm{C}$. After cooling to room temperature, peptides were dried, reconstituted in $20 \mu \mathrm{l}$ TEAB and labeled with iTRAQ ${ }^{\mathrm{TM}}$ reagent. In all experiments isobaric labeling exceeded $99 \%$ of total identified peptide using mass spectrometry. The four isobarically labeled reactions were pooled together and dried down.

\section{$\mathrm{TiO}_{2}$ phospho-enrichment}

The iTRAQ $^{\text {TM }}$ labeled peptide mixture was resuspended in $150 \mu \mathrm{l}$ of lactate loading buffer $(240 \mathrm{mg} /$ $\mathrm{ml}$ lactate in $80 \%(\mathrm{v} / \mathrm{v})$ Acetonitrile, $1 \%(\mathrm{v} / \mathrm{v})$ Trifluoroacetic acid (TFA). $\mathrm{TiO}_{2}$ columns (TopTip, Glygen, Corp, USA) were equilibrated with $150 \mu \mathrm{l}$ of lactate loading 
buffer then the samples loaded. The tip was washed twice with $60 \mu$ of lactate loading buffer and four times with 60 $\mu \mathrm{l}$ of wash buffer $(80 \%$ (v/v) Acetonitrile, $5 \%$ (v/v) TFA). Bound peptides were then recovered by elution in $60 \mu \mathrm{l}$ of elution buffer (ammonium water [20 $\mu \mathrm{NH}_{3}$ in $980 \mu \mathrm{l}$ $\left.\left.\mathrm{H}_{2} \mathrm{O}\right], \mathrm{pH} 10.5\right)$. samples were then concentrated to a few $\mu \mathrm{l}$ in a SpeedVac prior to Strong Cation Exchange (SCX) chromatography.

\section{SCX fractionation}

Enriched phosphopeptides were fractionated offline using an SCX cation exchange column $(10 \mathrm{~cm} \times 2.1$ mm PolyLCPolysulfoethyl A column, $5 \mu \mathrm{m}$ beads, $200 \mu \AA$ pore size (The Nest Group, Southborough, MA, USA) on a LC Packings Ultimate LC system running at $250 \mu \mathrm{l} / \mathrm{min}$. Peptides were diluted 10-fold in SCX loading buffer (10 $\mathrm{mM} \mathrm{KH}_{2} \mathrm{PO}_{4}$ in $25 \%$ (v/v) ACN, pH 2.7). The eluate was collected in $1 \mathrm{~min}$ intervals over the following gradient of increasing salt concentration: a 45 min linear gradient of 0-250 $\mathrm{mM} \mathrm{KCl}$, followed by a $10 \mathrm{~min}$ linear gradient of $250-500 \mathrm{mM} \mathrm{KCl}$, then $5 \mathrm{~min}$ of $1 \mathrm{M} \mathrm{KCl}$. Each fraction was then lyophilized in a SpeedVac concentrator (Labconco).

\section{Mass spectrometry}

Peptides were analyzed using a QStar ${ }^{\circledR}$ XL mass spectrometer (AB Sciex, Warrington, UK) as previously described [41]. Briefly, dried peptide fractions were resuspended in $120 \mu \mathrm{l}$ of Buffer A (2\% (v/v) acetonitrile $0.1 \%(\mathrm{v} / \mathrm{v})$ formic acid). For each analysis $60 \mu \mathrm{l}$ of sample was loaded onto a on-line column (15 length;75 $\mu \mathrm{m}$ inner diameter) packed with $\mathrm{RP} \mathrm{C}_{18}$ PepMap100 (3 $\mu \mathrm{m}, 100 \mathrm{~A}$ ) using a Ultimate pump (LC Packings, Amsterdam, Netherlands) and separated over a $120 \mathrm{~min}$ solvent gradient from $5.9 \%(\mathrm{v} / \mathrm{v})$ acetonitrile $/ 0.1 \%(\mathrm{v} / \mathrm{v})$ formic acid to $41 \%(\mathrm{v} / \mathrm{v})$ acetonitrile $/ 0.1 \%(\mathrm{v} / \mathrm{v})$ formic acid coupled to a QStar ${ }^{\circledR}$ XL mass spectrometer (AB Sciex, Warrington, UK). Data were acquired using an information dependent acquisition (IDA) designed with Analyst QS 2.0 (AB Sciex, Warrington, UK) where, for each cycle, the two most abundant multiply charged peptides $(2+$ to $4+)$ above a 20 count threshold in the MS scan with $\mathrm{m} / \mathrm{z}$ between 400 and 2000 were selected for MS/MS. Each ion was selected a maximum of two times, and then dynamically excluded ( $\pm 50 \mathrm{mmu}$ ) for 40 seconds.

\section{Data analysis}

Spectra were processed using ProteinPilot ${ }^{\mathrm{TM}}$ v.3 software (Paragon algorithm v.3.0.0.0, AB Sciex, Warrington, UK), searching against a mouse Celera Discovery System database (mouse_KBMS5_0_20050302, 115.660 entries). Default search parameters were set with
MS tolerance of $0.5 \mathrm{Da}, \mathrm{MS} / \mathrm{MS}$ tolerance of $0.1 \mathrm{Da}$. Identification focus was on biological modifications with phosphorylation emphasis as a special factor. Search parameters include methylmethanethiosulfonate (MMTS) alkylation of cysteine, iTRAQ ${ }^{\mathrm{TM}}$ modification of lysine and N-terminal residues. The searched parameter was set for reverse searching for false discovery, so that at the $95 \%$ confidence level there is a false positive identification rate of $<1 \%$. Ratio values for each phosphoentity were obtained from weighted averages of multiple spectra when appropriate, similarly to the way ProteinPilot ${ }^{\mathrm{TM}}$ calculates ratios for proteins. Phosphopeptides identified with a confidence $\geq 20$ were included in the analysis. ProteinPilot $^{\mathrm{TM}}$ biases were used to correct for any sampling error so that the median value of $\log 2$ (ratios) of the phosphoentity distribution is equal to 0 for each pair of $\mathrm{iTRAQ}^{\mathrm{TM}}$ reagents. The distribution of the biological replicates Control(Bry-Flk-):Control(Bry-Flk') was used to determine the biological variability of the procedure by combining the 2 control ratios. Student's $t$ test was performed between the values of 2 biological replicates for each appropriate ratio and the Gaussian distribution of the biological replicates. Phosphoentities with a Student's $t$-test $p$ value $<0.05$ were considered as potentially changing. Phosphoentities changing between the controls, i.e. for Bry Flk:Bry-Flk ratio, with a $p$ value $<0.05$ were manually removed from the analysis. All the phosphorylation events were validated manually using the spectral data acquired. The phospho-dataset was then compared with the dataset obtained from the total nuclear expression analysis [4].

\section{ACKNOWLEDGMENTS}

This work was supported by the Leukemia Lymphoma Research UK, Cancer Research UK, and an EMBO travel fellowship plus FIRB "Italian Human ProteomeNet" to Manuela Piazzi. Thanks to Dr. William L. Blalock and Dr. Alberto Bavelloni for critical reading of the manuscript.

\section{Author contributions}

MP, SP, RU, AW performed the experiments, AW and ADW, GL, VK designed the study. MP, ADW wrote the manuscript with LC and JAM.

\section{REFERENCES}

1. Huber TL, Kouskoff V, Fehling HJ, Palis J, Keller G. Haemangioblast commitment is initiated in the primitive streak of the mouse embryo. Nature. 2004; 432:625-30.

2. Xiong JW. Molecular and developmental biology of the hemangioblast. Developmental Dynamics. 2008; 237: 1218-31. 
3. Fehling HJ, Lacaud G, Kubo A, Kennedy M, Robertson S, Keller G, Kouskoff V. Tracking mesoderm induction and its specification to the hemangioblast during embryonic stem cell differentiation. Development. 2003; 130:4217-27.

4. Williamson AJK, Smith DL, Blinco D, Unwin RD, Pearson S, Wilson C, Miller C, Lancashire L, Lacaud G, Kouskoff V, Whetton AD. Quantitative proteomics analysis demonstrates post-transcriptional regulation of embryonic stem cell differentiation to hematopoiesis. Molecular \& Cellular Proteomics. 2008; 7:459-72.

5. O'Brien RN, Shen Z, Tachikawa K, Lee PJ, Briggs SP. Quantitative proteome analysis of pluripotent cells by iTRAQ mass tagging reveals post-transcriptional regulation of proteins required for ES cell self-renewal. Mol Cell Proteomics. 2010; 13.

6. Collins MO, Yu L, Choudhary JS. Analysis of protein phosphorylation on a proteome-scale. Proteomics. 2007; 7:2751-68.

7. Ben-Haim N, Lu C, Guzman-Ayala M, Pescatore L, Mesnard D, Bischofberger M, Naef F, Robertson EJ, Constam DB. The nodal precursor acting via activin receptors induces mesoderm by maintaining a source of its convertases and BMP4. Dev Cell. 2006; 11:313-23.

8. Pearson S, Sroczynska P, Lacaud G, Kouskoff V. The stepwise specification of embryonic stem cells to hematopoietic fate is driven by sequential exposure to Bmp4, activin A, bFGF and VEGF. Development. 2008; 135:1525-35.

9. Liu P, Wakamiya M, Shea MJ, Albrecht U, Behringer RR, Bradley A. Requirement for Wnt3 in vertebrate axis formation. Nat Genet. 1999; 22:361-5.

10. Kelly OG, Pinson KI, Skarnes WC. The Wnt co-receptors Lrp5 and Lrp6 are essential for gastrulation in mice. Development. 2004; 131:2803-15.

11. Huelsken J, Vogel R, Brinkmann V, Erdmann B, Birchmeier C, Birchmeier W. Requirement for beta-catenin in anterior-posterior axis formation in mice. J Cell Biol. 2000; 148:567-78.

12. Blair K, Wray J, Smith A. The liberation of embryonic stem cells. PLoS Genet. 2011; 7:e1002019.

13. McCubrey JA, Steelman LS, Bertrand FE, Davis NM, Abrams SL, Montalto G, D'Assoro AB, Libra M, Nicoletti F, Maestro R, Basecke J, Cocco L, Cervello M, et al. Multifaceted roles of GSK-3 and Wnt/beta-catenin in hematopoiesis and leukemogenesis: opportunities for therapeutic intervention. Leukemia. 2014; 28:15-33.

14. McCubrey JA, Davis NM, Abrams SL, Montalto G, Cervello M, Basecke J, Libra M, Nicoletti F, Cocco L, Martelli AM, Steelman LS. Diverse roles of GSK-3: tumor promoter-tumor suppressor, target in cancer therapy. Adv Biol Regul. 2014; 54:176-96.

15. Griaud F, Williamson AJ, Taylor S, Potier DN, Spooncer E, Pierce A, Whetton AD. BCR/ABL modulates protein phosphorylation associated with the etoposide-induced DNA damage response. J Proteomics. 2012; 15.

16. Pierce A, Williamson A, Jaworska E, Griffiths JR, Taylor S, Walker M, O'Dea MA, Spooncer E, Unwin RD, Poolman T, Ray D, Whetton AD. Identification of nuclear protein targets for six leukemogenic tyrosine kinases governed by post-translational regulation. PLoS One. 2012; 7:e38928.

17. Van Hoof D, Munoz J, Braam SR, Pinkse MW, Linding R, Heck AJ, Mummery CL, Krijgsveld J. Phosphorylation dynamics during early differentiation of human embryonic stem cells. Cell Stem Cell. 2009; 5:214-26.

18. Brill LM, Xiong W, Lee KB, Ficarro SB, Crain A, Xu Y, Terskikh A, Snyder EY, Ding S. Phosphoproteomic analysis of human embryonic stem cells. Cell Stem Cell. 2009; 5:204-13.

19. Huttlin EL, Jedrychowski MP, Elias JE, Goswami T, Rad R, Beausoleil SA, Villen J, Haas W, Sowa ME, Gygi SP. A tissue-specific atlas of mouse protein phosphorylation and expression. Cell. 2010; 143:1174-89.

20. Hsu PP, Kang SA, Rameseder J, Zhang Y, Ottina KA, Lim D, Peterson TR, Choi Y, Gray NS, Yaffe MB, Marto JA, Sabatini DM. The mTOR-regulated phosphoproteome reveals a mechanism of mTORC1-mediated inhibition of growth factor signaling. Science. 2011; 332:1317-22.

21. Joshi A, Coelho MB, Kotik-Kogan O, Simpson PJ, Matthews SJ, Smith CW, Curry S. Crystallographic analysis of polypyrimidine tract-binding protein-Raver1 interactions involved in regulation of alternative splicing. Structure. 2011; 19:1816-25.

22. Liu F, Chau KY, Arlotta P, Ono SJ. The HMG I proteins: dynamic roles in gene activation, development, and tumorigenesis. Immunol Res. 2001; 24:13-29.

23. Kirby LA, Schott JT, Noble BL, Mendez DC, Caseley PS, Peterson SC, Routledge TJ, Patel NV. Glycogen Synthase Kinase 3 (GSK3) Inhibitor, SB-21663, Promotes Pluripotency in Mouse Embryonic Stem Cells. PLoS One. 2012; 7:e39329.

24. Quentmeier H, Geffers R, Jost E, Macleod RA, Nagel S, Rohrs S, Romani J, Scherr M, Zaborski M, Drexler HG. SOCS2: inhibitor of JAK2V617F-mediated signal transduction. Leukemia. 2008; 22:2169-75.

25. Smith AG. Embryo-derived stem cells: of mice and men. Annu Rev Cell Dev Biol. 2001; 17:435-62.

26. Kiger AA, Jones DL, Schulz C, Rogers MB, Fuller MT. Stem cell self-renewal specified by JAK-STAT activation in response to a support cell cue. Science. 2001; 294:2542-5.

27. Schaniel C, Ang YS, Ratnakumar K, Cormier C, James T, Bernstein E, Lemischka IR, Paddison PJ. Smarcc1/Baf155 couples self-renewal gene repression with changes in chromatin structure in mouse embryonic stem cells. Stem Cells. 2009; 27:2979-91. 
28. Swaney DL, Wenger CD, Thomson JA, Coon JJ. Human embryonic stem cell phosphoproteome revealed by electron transfer dissociation tandem mass spectrometry. Proc Natl Acad Sci U S A. 2009; 106:995-1000.

29. Hutchins AP, Robson P. Unraveling the human embryonic stem cell phosphoproteome. Cell Stem Cell. 2009; 5:126-8.

30. Sharif J, Muto M, Takebayashi S, Suetake I, Iwamatsu A, Endo TA, Shinga J, Mizutani-Koseki Y, Toyoda T, Okamura K, Tajima S, Mitsuya K, Okano M, et al. The SRA protein Np95 mediates epigenetic inheritance by recruiting Dnmt1 to methylated DNA. Nature. 2007; 450:908-12.

31. Meilinger D, Fellinger K, Bultmann S, Rothbauer U, Bonapace IM, Klinkert WE, Spada F, Leonhardt H. Np95 interacts with de novo DNA methyltransferases, Dnmt3a and Dnmt3b, and mediates epigenetic silencing of the viral CMV promoter in embryonic stem cells. EMBO Rep. 2009; 10:1259-64.

32. Bonapace IM, Latella L, Papait R, Nicassio F, Sacco A, Muto M, Crescenzi M, Di Fiore PP. Np95 is regulated by E1A during mitotic reactivation of terminally differentiated cells and is essential for S phase entry. J Cell Biol. 2002; 157:909-14.

33. Muto M, Kanari Y, Kubo E, Takabe T, Kurihara T, Fujimori A, Tatsumi K. Targeted disruption of Np95 gene renders murine embryonic stem cells hypersensitive to DNA damaging agents and DNA replication blocks. J Biol Chem. 2002; 277:34549-55.

34. Yuan H, Mao J, Li L, Wu D. Suppression of glycogen synthase kinase activity is not sufficient for leukemia enhancer factor-1 activation. J Biol Chem. 1999; 274:30419-23.

35. McCubrey JA, Steelman LS, Bertrand FE, Davis NM, Sokolosky M, Abrams SL, Montalto G, D'Assoro AB,
Libra M, Nicoletti F, Maestro R, Basecke J, Rakus D, et al. GSK-3 as potential target for therapeutic intervention in cancer. Oncotarget. 2014; 5:2881-911.

36. Goc A, Al-Husein B, Katsanevas K, Steinbach A, Lou U, Sabbineni H, DeRemer DL, Somanath PR. Targeting Srcmediated Tyr216 phosphorylation and activation of GSK-3 in prostate cancer cells inhibit prostate cancer progression in vitro and in vivo. Oncotarget. 2014; 5:775-87.

37. Campa VM, Baltziskueta E, Bengoa-Vergniory N, GorronoEtxebarria I, Wesolowski R, Waxman J, Kypta RM. A screen for transcription factor targets of glycogen synthase kinase-3 highlights an inverse correlation of NFkappaB and androgen receptor signaling in prostate cancer. Oncotarget. 2014; 5:8173-87.

38. Singhal N, Graumann J, Wu G, Arauzo-Bravo MJ, Han DW, Greber B, Gentile L, Mann M, Scholer HR. Chromatin-Remodeling Components of the BAF Complex Facilitate Reprogramming. Cell. 2010; 141:943-55.

39. Ying QL, Wray J, Nichols J, Batlle-Morera L, Doble B, Woodgett J, Cohen P, Smith A. The ground state of embryonic stem cell self-renewal. Nature. 2008; 453:519-23.

40. Wray J, Kalkan T, Gomez-Lopez S, Eckardt D, Cook A, Kemler R, Smith A. Inhibition of glycogen synthase kinase-3 alleviates Tcf3 repression of the pluripotency network and increases embryonic stem cell resistance to differentiation. Nat Cell Biol. 2011; 13:838-45.

41. Unwin RD, Pierce A, Watson RB, Sternberg DW, Whetton AD. Quantitative proteomic analysis using isobaric protein tags enables rapid comparison of changes in transcript and protein levels in transformed cells. Mol Cell Proteomics. 2005; 4:924-35. 